\title{
Substitution of amalgam restorations: participative training to standardize criteria
}

\section{Substituição de restaurações de amálgama: um treinamento participativo para padronização de critérios}

\author{
Elaine Toledo Pitanga Fernandes* \\ Efigênia Ferreira e Ferreira**
}

\begin{abstract}
Considering that the variations on clinical judgment with respect to replacement of restorations are a problem which affects dentistry, the aim of this study was to elaborate, implement and evaluate a programme of participative training to standardize criteria for the evaluation of amalgam restorations. Five professors of Integrated Clinic of the School of Dentistry of the University of Vale do Rio Doce (UNIVALE), Brazil, visually and radiographically evaluated 28 extracted permanent teeth presenting amalgam restorations. The research was developed in four distinct phases: first - the teeth were evaluated according to individual criteria to determine whether restorations should be replaced or not; second - the examiners participated in a training programme with the objective of standardizing the evaluation criteria; third - soon after the training, the teeth were re-evaluated using the adopted standardized criteria; fourth - five months after the training, the procedures on third phase were repeated. For each restoration the examiners registered the main reason for considering the restoration: satisfactory, requiring total substitution, requiring partial substitution or requiring finishing/polishing. After participating in the training programme the examiners presented a statistically significant reduction ( $\operatorname{sign}$ test: $Z=0.4989, p=0.0022$ ) in indicating the need to substitute restorations, result which was maintained five months after training. This programme of participative training can be organized and implemented to standardize the criteria to evaluate amalgam restorations achieving satisfactory results with an impact on clinical practice.
\end{abstract}

DESCRIPTORS: Dental amalgam; Dental restoration, permanent.

\begin{abstract}
RESUMO: Considerando que variação no julgamento clínico de substituição das restaurações é um problema que afeta a maioria dos profissionais, objetivou-se neste trabalho elaborar, implementar e avaliar um programa de treinamento participativo para padronização de critérios na avaliação de restaurações de amálgama. Cinco professores da Disciplina de Clínica Integrada do Curso de Odontologia da Universidade Vale do Rio Doce (UNIVALE) avaliaram através de exame visual e radiográfico 28 dentes permanentes extraídos contendo restaurações de amálgama. Na $1^{\mathrm{a}}$ fase deste estudo, os examinadores avaliaram os dentes conforme seus critérios individuais para substituição ou permanência das restaurações. $\mathrm{Na} 2^{\mathrm{a}}$ fase, os examinadores participaram de um programa de treinamento objetivando padronizar os critérios de avaliação. $\mathrm{Na} 3^{\mathrm{a}}$ fase, logo após o treinamento, reavaliaram os dentes com critérios já padronizados. $\mathrm{Na} 4^{\mathrm{a}}$ fase, cinco meses após o treinamento, repetiram-se os procedimentos da $3^{\mathrm{a}}$ fase. Para cada restauração, os examinadores registravam em formulário próprio a principal razão para considerá-la satisfatória, com necessidade de substituição total, com necessidade de substituição parcial ou com necessidade de acabamento/polimento. Após a participação no programa de treinamento, o grupo de examinadores apresentou uma redução estatisticamente significante ("sign test": $Z=0,4989, p=0,0022$ ) na indicação de substituição das restaurações, resultado que se manteve, mesmo decorridos cinco meses após o treinamento. É possível organizar e implementar um programa de treinamento participativo para padronização de critérios na avaliação de restaurações de amálgama e obter resultados satisfatórios com impacto na prática clínica.
\end{abstract}

DESCRITORES: Amálgama dentário; Restauração dentária permanente.

\section{INTRODUCTION}

Amalgam has been extensively used as a dental restorative material for more than 150 years. Because of factors such as cost, simplicity of use, adequate mechanical properties and durability amalgam is still the material of choice for restorations in posterior teeth ${ }^{6}$.

In spite of continuous improvements to its properties, the number of amalgam restorations

\footnotetext{
* MSc, Senior Lecturer in General Dentistry, School of Dentistry, University of Vale do Rio Doce.

** PhD, Senior Lecturer in General Dentistry, Primary Care, School of Dentistry, Federal University of Minas Gerais.
} 
Fernandes ETP, Ferreira EF. Substitution of amalgam restorations: participative training to standardize criteria. Braz Oral Res 2004; 18(3):247-52.

replaced remains large. Studies confirm that dental surgeons spend more than half of their clinical time replacing restorations ${ }^{7}$.

Studies undertaken with the objective of analyzing the causes of these substitutions have found secondary caries as the most frequent reason reported ${ }^{10,11,20}$. However, other reasons have also been identified, such as restoration fractures, marginal infiltration, deficient anatomical form and over-contouring of restorations ${ }^{13}$. Mjör, Toffenetti $^{12}$ (2000) confirm that, although clinical diagnosis of secondary caries is the most common reason to substitute a restoration, scientific basis for this diagnosis is weak.

Among other factors, the lifetime of a restoration depends on the criteria used to diagnose failures or, in other words, the need for substitution ${ }^{14}$. Attempts have been made to establish and standardize these criteria with the objective of finding more realistic and accurate criteria to clinically evaluate restorations ${ }^{1,18}$. However, the quality of restorations is still based on subjective parameters which are difficult to define and frequently subject to the individual criteria applied by each professional ${ }^{5}$.

Uncertainties in clinical evaluation lead to unnecessary substitutions, reducing lifetime of restorations ${ }^{19}$, as well as life expectancy of teeth ${ }^{14}$. The large number of substitutions of restorations which are undertaken in the Discipline of Integrated Clinic of the Dentistry Course in the School of Health Sciences (FACS) in the University of Vale do Rio Doce (UNIVALE) led to the development of this research. Its objective was to elaborate, implement and evaluate a programme of participative training for selection and standardization of criteria to evaluate amalgam restorations, based on the evaluation of a group of professors of Integrated Clinic.

\section{MATERIAL AND METHODS}

The group of examiners consisted of professors, each with a clinical experience of 15 to 25 years. These professors are supervisors of the Discipline of Integrated Clinic of the dentistry course of the FACS of the UNIVALE. A total of 28 permanent human teeth extracted for clinical reasons were chosen. These teeth had class I (14) or class II (14) restorations with doubtful characteristics regarding the need for amalgam replacement based on the criteria described in the literature. Teeth with obvious carious lesions were not included.
Lifetime of the restorations and type of alloy used were not taken into consideration. This study was approved by the Committee of Ethics in Research of the Federal University of Minas Gerais (UFMG) (ETIC 155/99).

Soon after extraction the teeth were decontaminated in a solution of buffered $10 \%$ formaldehyde (Laboratory of the School of Dentistry, Federal University of Minas Gerais, BH, Brazil) ${ }^{4}$, mechanically cleaned [low-speed handpiece with a Robson brush (Dentamerica, California, USA) and polishing paste (Herjos-F, Rio de Janeiro, Brazil)], and fixed in blocks of acrylic resin (Artigos Odontológicos Clássico Ltda., SP, Brazil). Four teeth were fixed in each block, of which two were restored and the other two (did not belong to the sample) were used to maintain interproximal contacts and simulate a clinical situation. After being identified, the blocks were stored in saline solution (Sidepal, Guarulhos, Brasil) to avoid the dehydration of the samples. Each block was X-rayed (buccolingual direction) to obtain radiographs comparable to bitewing radiographs ${ }^{17}$.

The research was developed in four distinct phases:

- In the first phase (pre-training) the restorations were evaluated by the examiners according to the need for replacement or not of the restoration through visual examination and radiographic analysis using the examiner's personal criteria. An exploratory probe was not used because it was considered inappropriate and contra-indicated for the clinical evaluation of restorations ${ }^{8}$. The radiographic exam was undertaken with the aid of a light box.

For each restoration the examiners stated in writing if the restoration in question was satisfactory, required total replacement, required partial replacement (stating the location of the problem) or required finishing/polishing (stating the location of the problem). The same protocol was followed for the evaluation in the post-training phases.

- In the second phase, aiming at standardizing the evaluation criteria of restorations, all examiners engaged in a training programme (four sessions with fortnightly intervals), that consisted of: theoretical basis, calibration with slides, calibration with extracted teeth and the development of a table of criteria. The duration of these sessions was of 1 and a half hours, and the sessions were participative. 
Fernandes ETP, Ferreira EF. Substitution of amalgam restorations: participative training to standardize criteria. Braz Oral Res 2004;18(3):247-52.

TABLE 1 - Frequency of need for substitution or not (percentage) of amalgam restorations evaluated by five examiners, before and after the training programme.

\begin{tabular}{|c|c|c|c|}
\hline Evaluation & Pre-training (\%) & Post-training (\%) & Verification (\%) \\
\hline Substitution (total and partial) & $44^{*}$ & $31^{*}+$ & $33+$ \\
\hline $\begin{array}{l}\text { Substitution not indicated (satisfactory and need } \\
\text { for finishing and polishing) }\end{array}$ & $56^{*}$ & $69 *+$ & $67+$ \\
\hline
\end{tabular}

${ }^{*}$ Sign test: $Z=0.4989, p=0.0022$ (pre- and post-training); +sign test: $Z=0.199, p=0.61$ (post-training and verification).

- In the third phase (post-training), at the same interval, the blocks of teeth examined in the first phase (pre-training) were re-numbered, and re-evaluated by the examiners who were unaware that they were evaluating the same teeth. The evaluation of the teeth proceeded in the same way as in the first phase. However, instead of using individual criteria the participants used the criteria standardized during the training phase.

- In the fourth phase (verification), five months after the end of the training programme, aiming to evaluate the retention of knowledge, the procedure of the third phase was repeated.

\section{RESULTS AND DISCUSSION}

The training programme induced a reduction of $13 \%$ in the need to replace restorations (Table 1). This result was statistically significant (sign test: $Z=0.4989, p=0.0022)$. Relating this percentage to the total number of exams (28 teeth examined by 5 examiners - 140 exams) we can see that eighteen restorations would have been substituted unnecessarily if only individual criteria were used. Therefore, if need for replacement had been based on the standardized criteria, damage to teeth could be avoided, and there would be a cost reduction of the treatment.

The retention of knowledge was demonstrated when we see that the percentage of substitution in the verification and post-training phase remains stable (sign test: $Z=0.199, \mathrm{p}=0.61$ ) (Table 1 ).

Graph 1 shows the changes in diagnoses before and after training and in the verification phases due to changes in behaviour.

The changes in behaviour can be observed based on the significant increase of $27 \%$ (from $15 \%$ to $42 \%$ ) in the number of restorations considered satisfactory (Graph 1) and also based on the reduction of need for replacement (total and partial) and the reduction of need for finishing and polishing, besides the variation of reasons reported

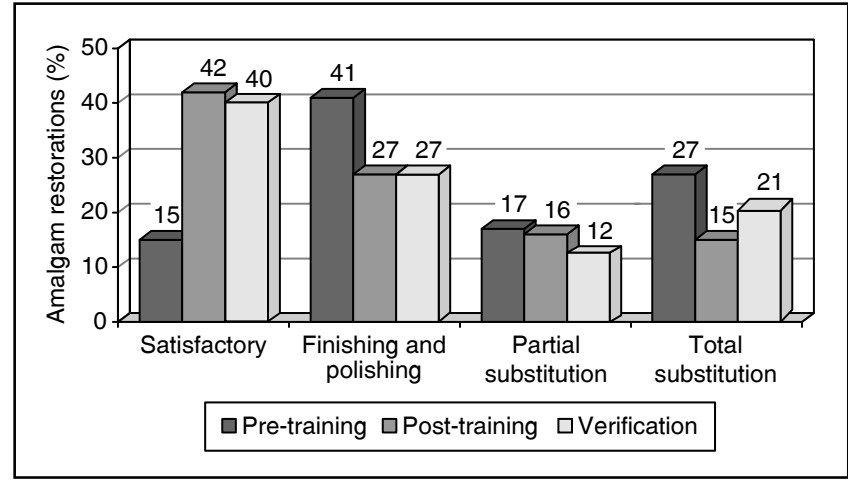

GRAPH 1 - Comparison of the results of the evaluation of amalgam restorations undertaken by five examiners before and after the training programme and in the verification phase.

to justify the need to substitute the restorations evaluated (Table 2).

Secondary caries were found to be the main reason to substitute amalgam restorations ${ }^{7,10,20}$. However, in this study, in the pre-training phase, the examiners indicated problems of marginal adaptation as the principal reason to substitute amalgam restorations (Table 2), a result also found by Nuckles et al. ${ }^{13}$ (1991). Secondary caries appeared as the forth $(9.46 \%)$ reason for the need for substitution (total or partial) and was observed only in the pre-training phase.

The previously cited studies that reported secondary caries as the main reason for the substitution of amalgam restorations are transverse in design and in vivo ${ }^{12}$. These studies reflect everyday dental practice and were undertaken with the aim to evaluate the prevalence and reasons for substituting restorations in a particular location. The examiners were not calibrated and the samples were not pre-selected. In this study, the sample of teeth was pre-selected to allow the calibration of examiners following already established criteria for the evaluation of amalgam restorations. Therefore, the reasons for different results may be due to the difference in the aims and design of the studies ${ }^{12}$. 
Fernandes ETP, Ferreira EF. Substitution of amalgam restorations: participative training to standardize criteria. Braz Oral Res 2004;18(3):247-52.

TABLE 2 - Frequency of reasons (absolute value) reported by the examiners to justify the need for partial or total substitution, or finishing and polishing (before and after the training programme).

\begin{tabular}{|c|c|c|c|c|}
\hline Evaluation & Reason & Pre-training & Post-training & Verification \\
\hline \multirow{7}{*}{$\begin{array}{l}\text { Total } \\
\text { substitution }\end{array}$} & $\begin{array}{l}\text { Problems with marginal adaptation of the } \\
\text { restoration* }\end{array}$ & 19 & 4 & 5 \\
\hline & Lack of contouring & 8 & - & - \\
\hline & Porosity & 8 & 3 & - \\
\hline & Secondary caries & 7 & - & 4 \\
\hline & $\begin{array}{l}\text { Cervical defects (excess or lack of restorative } \\
\text { material) }\end{array}$ & 6 & 6 & 6 \\
\hline & Lack of proximal contacts & 2 & 5 & 6 \\
\hline & Fracture (tooth or restoration) & 1 & 2 & 1 \\
\hline \multirow{4}{*}{$\begin{array}{l}\text { Partial } \\
\text { substitution }\end{array}$} & $\begin{array}{l}\text { Problems with marginal adaptation of the } \\
\text { restoration* }\end{array}$ & 8 & 3 & 2 \\
\hline & $\begin{array}{l}\text { Cervical defects (excess or lack of restorative } \\
\text { material) }\end{array}$ & 8 & 6 & 3 \\
\hline & Lack of proximal contacts & 4 & 7 & 2 \\
\hline & Fracture (tooth or restoration) & 3 & 6 & 6 \\
\hline \multirow{4}{*}{$\begin{array}{l}\text { Finishing and } \\
\text { polishing }\end{array}$} & Improve contouring or anatomy & 18 & - & 1 \\
\hline & Superficial roughness & 15 & 17 & 15 \\
\hline & Over-contouring of margins & 6 & 17 & 6 \\
\hline & Cervical defects (excess of restorative material) & 5 & 4 & 4 \\
\hline
\end{tabular}

*Each examiner could choose more than one response: marginal infiltration, loss of continuity, poor adaptation, deficient cavosurface sealing.

The reporting of problems of marginal adaptation as a reason for substitution (total or partial) reduced from 27 teeth in the pre-training phase to seven in the post-training phase, as well in the verification phase. The behaviour of the examiners in the pre-training phase was expected, since many professionals wrongly associate marginal defects in restorations with secondary caries and, therefore, recommend unnecessary substitutions ${ }^{5,11,12}$. The change in the approach of the examiners in the post-training phase probably resulted from the change of emphasis during the training because marginal defects were not included in the criteria that justified substitution of a restoration ${ }^{1,8,16}$.

Barbakow et al. ${ }^{2}$ (1988) showed that $100 \%$ of amalgam restorations show marginal defects six months after placement. Therefore, deficiency in marginal integrity is not a reason to substitute a restoration. Periodical recalls to monitor restorations and the caries risk of patients or to repair margins are preferable to total substitution ${ }^{15}$. This approach seems to have been a consensus among the examiners in the post-training phase, since there was an increase in the number of reports of over-contouring of margins (from six to seventeen) with the indication of need for finishing and polishing rather than substitution.

Analyzing Table 2, we observe a marked reduction from the pre- to the post-training phase through the excessive worry about the contouring of restorations, both as need for substitution (from eight to zero) and finishing and polishing (from eighteen to zero). Since the era of Black, the quality of restorations has been associated to smooth, polished and intact margins. If restorations did not comply with this standard appearance they would have to be replaced ${ }^{9}$. The evaluations of the examiners in the pre-training phase were expected, representing the conduct adopted by the majority of professionals. The post-training phase reflects a change in behaviour of the examiners. Restorations that were previously deficient were considered clinically acceptable. Taking into account the number of years of clinical experience of the examiners, who were used to an essentially restorative dentistry, these results can be considered very satisfactory.

The criterion of absence of proximal contacts was less reported as a reason for substitution in the pre-training than in the post-training phase. 
Fernandes ETP, Ferreira EF. Substitution of amalgam restorations: participative training to standardize criteria. Braz Oral Res 2004;18(3):247-52.

This confirms the excessive worry of the examiners about superficial aspects of the restoration masking functional defects in their evaluation before training. During training there was a consensus that absence of proximal contacts is a reason to replace a restoration due to the damage that could be caused to the periodontium. This explains the increase in the number of times that this criterion was used as a reason to substitute restorations after training.

The programme of training tested in this study was initiated by a process of deepening our theoretical understanding before the elaboration of the table of criteria (literature review, group participation, consensus and development in writing to facilitate understanding, resulting in clinical application). The high level of cooperation and participation within the group was a factor that facilitated discussion and consensus.

The methodology of the training programme included two sessions of calibration: the first one with slides and the second with permanent human extracted teeth, containing amalgam restorations, as suggested by Courts ${ }^{3}$ (1997). The examiners reported greater difficulty in agreement when evaluating the restorations of extracted teeth compared to those of the slides, reporting that defects were more evident on slides due to higher magnification.

During the evaluation of the training programme the examiners emphasized the importance of the two week intervals between sessions which allowed time to assimilate the new discussed concepts, rethink their behaviour and consider the clinical implications. The participants recognized their changes in attitude from one session to another reporting how their new concepts had been applied clinically.

\section{REFERENCES}

1. Anusavice KJ. Criteria for placement and replacement of dental restorations. J Dent Res 1988;67:795-6.

2. Barbakow F, Geberthuel T, Lutz F, Schuepbach P. Maintenance of amalgam restorations. Quintessence Int 1988;19:861-70.

3. Courts FJ. Standardization and calibration in the evaluation of clinical performance. J Dent Educ 1997;61:94750.

4. Deery C, Fyffe HE, Nugent $Z$, Nuttall NM, Pitts NB. The effect of placing a clear pit and fissure sealant on the validity and reproducibility of occlusal caries diagnosis. Caries Res 1995;29:377-81.
Five months after the conclusion of the training programme the group of examiners re-examined the same teeth following the same methodology. It is important to emphasize that during this period of time there was no formal contact between the researcher and the group. This disguised the fact that a new evaluation would be undertaken. A small increase was found in the need for replacement of amalgam restorations in this verification phase $(33 \%)$ when compared with the post-training phase $(31 \%)$. This result was not statistically significant (sing test: $Z=0.199 p=0.61$ ) but confirms the maintenance of the results reached after participation in the training programme.

It should be emphasized that in a clinical situation the application of criteria developed during the calibration using extracted teeth cannot be separated from the inherent needs of the patient.

These new concepts should be incorporated into the dentistry curriculum so that students do not start practicing without defined criteria for the evaluation of amalgam restorations to the benefit of the community served.

\section{CONCLUSIONS}

A programme of participative training can be organized and implemented to standardize the criteria for the evaluation of amalgam restorations with satisfactory results having an impact in clinical practice.

The possibility of using this methodology for other aspects of clinical practice widens the possibility of other calibrations which will significantly benefit teaching and consequently quality of treatment offered by future professionals.

5. Elderton RJ. Clinical studies concerning re-restoration of teeth. Adv Dent Res 1990;4:4-9.

6. Felipe LA, Vieira LCC, Danker AL. Amálgama dental: fatos e controvérsias. Rev Assoc Paul Cir Dent 1999;53:41-5.

7. Friedl KH, Hiller KA, Schmalz G. Placement and replacement of amalgam restorations in Germany. Oper Dent 1994;19:228-32.

8. Kidd EAM. Caries diagnosis within restored teeth. Adv Dent Res 1990;4:10-3.

9. Maryniuk GA. Replacement of amalgam restorations that have marginal defects: variation and cost implications. Quintessence Int 1990;21:311-9. 
Fernandes ETP, Ferreira EF. Substitution of amalgam restorations: participative training to standardize criteria. Braz Oral Res 2004;18(3):247-52.

10. Mjör IA. The reasons for replacement and the age of failed restorations in general dental practice. Acta Odontol Scand 1997;55:58-63.

11. Mjör IA, Qvist V. Marginal failures of amalgam and composite restorations. J Dent 1997;25:25-30.

12. Mjör IA, Toffenetti F. Secondary caries: a literature review with case reports. Quintessence Int 2000;31:16578.

13. Nuckles DB, Sneed WD, Bayne JB, Collins DE, Hook CR, Welsh EL. Faculty differences in replacement decisions for amalgam restorations. Quintessence Int 1991;22:53340.

14. Oleinisky JC, Baratieri LN, Ritter AV, Felipe LA, Freitas SFT. Influence of finishing and polishing procedures on the decision to replace old amalgam restorations: an in vitro study. Quintessence Int 1996;27:833-9.

15. Paterson FM, Paterson RC, Watts A, Blinkhorn AS. Initial stages in the development of valid criteria for the replacement of amalgam restorations. J Dent 1995;23:13743.
16. Pimenta LAF, Navarro MFL, Consolaro A. Secondary caries around amalgam restorations. J Prosthet Dent 1995;74:219-22.

17. Rudolphy MP, van Amerongen JP, Penning $\mathrm{CH}$, ten Cate JM. Validity of bite-wings for diagnosis of secondary caries in teeth with occlusal amalgam restorations in vitro. Caries Res 1993;27:312-6.

18. Ryce C, Mjör IA. Avaliações clínicas diretas. In: Hörsted-Bindslev P, Mjör IA. Dentística Operatória Moderna. $2^{a}$ ed. São Paulo: Santos; 1993. p. 269-83.

19. Serra MC, Pimenta LAF, Paulillo LAMS. Dentística e manutenção de saúde bucal. In: Kriger L (Coordenador). ABOPREV Promoção de saúde bucal. São Paulo: Artes Médicas; 1997. p. 201-54.

20. Wilson NHF, Trevorburke FJ, Mjör IA. Reasons for placement and replacement of restorations of direct restorative materials by a selected group of practioners in the United Kingdom. Quintessence Int 1997;28:245-8.

Received for publication on Sep 23, 2003

Sent for alterations on May 13, 2004 Accepted for publication on Jun 07, 2004 